\title{
Charles Brewster of Fort Madison: A Profile in Enterprise, 1845-1875
}

\author{
John E. Pilcher
}

BEGINNING IN 1833, a number of villages sprang up along the western bank of the Mississippi River in the territory that would become Iowa. Each town boasted of its geographic location, salubrious climate, and potential for growth in mixed tones of hopeful expectations and anxious doubts. Although their ultimate degrees of success varied greatly, their origins and prospects for attracting population growth and the firm foundations of trade and commerce were initially similar. Three such embryonic urban centers and potential trade rivals were Burlington, Fort Madison, and Keokuk. All three were platted about the same time, Burlington in 1833, Fort Madison in 1835, and Keokuk in 1837. All three villages grew slowly in their first few years, but by 1850 , distinctions were already apparent. Burlington had profited by becoming successively the temporary capital of Wisconsin Territory in 1836 and of Iowa Territory in 1838. Keokuk had begun to capitalize on its location at the head of the rapids on the Mississippi in trans-shipment and emigrant traffic. In 1850, the federal population census reported Burlington with 4,060, Keokuk with 2,478, and Fort Madison with 1,509. From 1850 on, the true rivalry was between Burlington and Keokuk, with Fort Madison running a very distant third. Though Fort Madison lived in the shadow of its more illustrious neighbors, it achieved a quiet and gradual success, and some of its citizens achieved prosperity. One of these was a 
prominent dry goods merchant and banker, Charles Brewster. ${ }^{1}$

Charles Brewster was born in Ireland in 1813, and he was brought to the United States at the age of twelve by an uncle, in whose Philadelphia home he grew up. When Brewster was twenty-three, the uncle's business in Philadelphia failed, so the young man moved to Vincennes, Indiana, where he remained for six years. He worked for a short time in the federal land office in Vincennes (possibly as a clerk), and then he entered the dry goods business. The county history accounts do not specify whether Brewster had his own dry goods store in Vincennes or clerked in someone else's store, but the latter seems more likely. In 1844, Brewster moved to Fort Madison, Iowa Territory, and opened the dry goods store there which he operated successfully for thirty years. ${ }^{2}$

In 1875, he formed a banking partnership with Dr. Joseph A. Smith, with whom he bought the Bank of Fort Madison. He was president of that bank until 1888, when it merged with the First National Bank of Fort Madison, and he served on the board of directors of the successor institution. In August, 1890, the stockholders of the First National Bank organized a sister banking enterprise, the Fort Madison Savings Bank, of which he was president until his retirement. ${ }^{3}$ Brewster died November 12,1893 , survived by the three children from his second marriage, James C., William, and Martha. His son James C. Brewster followed him into banking, becoming vice-president of the

${ }^{1}$ The History of Des Moines County, Iowa (Chicago: Western Historical Company, 1879), 473; The History of Lee County, Iowa (Chicago: Western Historical Company, 1879), 595, 616; The Seventh Census of the United States: 1850, Statistics, 1 (Washington: Robert Armstrong, Public Printer, 1853), 945, 947; Fort Madison did not reach a total population of 4,000 until 1870 , when 4,011 residents were counted. The Census of Iowa As Returned in the Year 1873 ... (Des Moines: E. P. Clarkson, State Printer, 1874), 82.

${ }^{2}$ Charles Brewster Papers, Folder 1, Manuscript Collections, Division of the State Historical Society of Iowa, Iowa City, Iowa, hereafter cited as DSHS.

${ }^{3}$ Story of Lee County, Iowa, 1 (Chicago: The S. J. Clarke Publishing Company, 1914), 255. The year of his retirement is not given, but a city directory lists him as "retired banker" in 1890. Showers and Easterly's Fort Madison City Directory for 1890-91 (Quincy, Illinois: Showers and Easterly, 1890), 19. 
Fort Madison Savings Bank, and later, president of the German-American Bank of Fort Madison. ${ }^{4}$

What these biographical accounts show, in oversimplified fashion, is the story of an apparently capable man who was successful both as a dry goods merchant and as a banker. There is no explained connection between the two careers, and the implication is that Brewster simply shifted his attention, talents, and capital from one to the other. This was hardly the case. In varying degrees, Charles Brewster was a banker in an informal sense for at least twenty-eight years before he made the formal change in principal occupations. The key word in this phrase is "principal." Up until his formal shift in principal occupations, Brewster engaged in a number of economic enterprises, supplementary to his mercantile trade, which included wholesaling of farm commodities, banking services, speculation in state auditor's warrants, land dealings, and mortgages.

He was certainly not unique in his varied economic interests. Western merchants in this period of Brewster's first career, 1845 to 1875 , were not confined to retailing their stock of goods over the counter. Quite often, they were simultaneously engaged in a number of auxiliary economic enterprises, some out of convenience and others out of sheer necessity. An example in earlier days was the Kaskaskia merchant, William Morrison, who traded furs, contracted supplies to military posts, distributed mail, owned mills, ferries, flatboats, a bridge, and thousands of acres of public domain and private claims land in the Midwest. ${ }^{5}$ From his studies of western merchants, Lewis Atherton constructed a model for the nineteenth century frontier merchant and the functions he performed. Briefly outlined, these functions included town building, wholesaling and retailing, banking services, developing markets for farm crops, promotion of agriculture and manufacturing, and various social services to the community. ${ }^{6}$ Although Atherton focused on the period up

${ }^{4}$ Fort Madison Evening Democrat, Nov. 13, 1893; Biographical Review of Lee County, Iowa (Chicago: Hobart Publishing Company, 1905), 52-53.

${ }^{5}$ John Leslie Tevebaugh, "Merchant on the Western Frontier: William Morrison of Kaskaskia, 1790-1837" (M.A. thesis, Illinois, 1962).

${ }^{6}$ Lewis E. Atherton, The Frontier Merchant in Mid-America (Columbia: University of Missouri Press, 1971), 22-25. 
to the middle to late 1840s, his general model is still useful in examining the activities of later merchants located in areas that could be no longer termed frontiers.

Charles Brewster's principal business in the years 1845 to 1875 was his dry goods store in Fort Madison. An exact economic analysis of this establishment is not possible because of the absence of a variety of requisite records. Absent are the "daybooks" which detailed daily transactions, ledgers of individual accounts, general periodic statements of profits and losses, or even copy books containing copies of business letters Brewster wrote. What remains is a wealth of business letter correspondence from customers, wholesalers, and others. Also surviving are a fairly complete collection of merchandise invoices and receipts, a few early municipal tax and county road tax receipts, a few promissory notes issued in credit transactions, and a miscellany of other papers. Taken together, the manuscript collection yields information not only about Brewster's store, but also about Brewster's trade relationships with others, and how the store served as the hub of all of Brewster's enterprises.

The dry goods store was located on parts of Lots 126 and 127 a on Front Street in the old business district of Fort Madison which grew up near the river front. Brewster operated his store at this location continuously from 1847, when he first bought the property, until $1875 .{ }^{7}$ Brewster continuously referred to himself in newspaper advertisements as a "dealer in dry goods," but this self-description is somewhat misleading. That he dealt in bolts of cloth, ribbons, and certain ready-made clothes is true, and he apparently did so in volume. In addition to a long list of yard goods (including wools, cotton prints, muslin, gingham, and satin), Brewster also carried teas, coffee, sugar, flour, salt, pepper and other spices, and dried fruit in the grocery section. His hardware line included wash tubs, buckets, ax handles, butter churns, rolling pins, rope, bar iron, coffee mills, latches, locks, and sad irons. He stocked patent medicines, stationery supplies, soap, shoes, boots and trunks, umbrellas, men's hats

${ }^{7}$ Lee County (Iowa) Deed Records Lands, 3 (1845-1848), 422. He moved to that location from another in the same immediate vicinity where presumably he had first opened his store, Cf. municipal tax receipts for 1845 and 1846 on Lot 140, Brewster Papers, Folder 1, DSHS. 


\section{The Annals of Iowa}

and boys' caps, dishes, cigars and plug tobacco ${ }^{8}$

His store certainly was not unique in its variety of merchandise. In addition to common items, Brewster stocked such finery as black silk cravats, Irish linen, and ladies' kid gloves in 1854, when the total population of Lee County was 22,590, and the total state population of Iowa was $324,401 .^{9}$ The Burlington merchants, Bridgeman and Partridge, had offered all of these items as early as 1839 , when Iowa Territory contained fewer than 43,000 inhabitants. ${ }^{10}$ This variety of merchandise was not restricted in later years, even after a regular local trade had been established. A perusal of invoices indicates that if anything, the variety expanded somewhat in the later years, particularly after the Civil War, when the combination of rapid rail transportation and proliferation of new manufacturing increased the range of articles available in the consumer goods market. ${ }^{11}$

Brewster acquired his stock of merchandise from a variety of wholesalers. His choices among them in the early years may have been dictated as much by personal preferences as by trade routes and transportation patterns. Lewis Atherton noted that Philadelphia was the primary national wholesale center for western merchants until 1850. After that, New York drew a greater volume of business from merchants in northern Illinois and in Iowa. Chicago, by 1850 , had begun to challenge St. Louis as the most important local supply center. ${ }^{12}$

Reflecting these trends, Brewster bought the bulk of his goods almost exclusively from Philadelphia before 1850 . He may have done so, to some degree, out of loyalty to his former home city and personal acquaintances with some of the leading Philadelphia wholesale merchants. In addition, it appears that the Phil-

\footnotetext{
${ }^{8}$ Brewster Papers, Folders 18-21, DSHS.

'John A. T. Hull, ed., Census of Iowa for 1880 and the Same Compared with the Findings of Each of the Other States and Also with all Former Enumerations of the Territory Now Embraced Within the Limits of the State of Iowa ... .(Des Moines: F. M. Mills, State Printer and Geo. E. Roberts, State Printer, 1883), 196-197, xliv.

${ }^{10}$ The Hawkeye and Iowa Patriot, Dec. 12, 1839; Hull, Census of Iowa for 1880, xliv, 4.

${ }^{11}$ Brewster Papers, Folders 18-21, DSHS.

${ }^{12}$ Atherton, The Frontier Merchant in Mid-America, 60.
} 
adelphia houses granted him liberal credit terms. In 1845, the firm of Barcroft Beaver and Company took his promissory note, at ten percent interest per annum, for $\$ 1,354.90$. Three years later, in 1848 , the same firm took his note for $\$ 2,486.57$, again at ten percent interest. While the total amounts Brewster bought and the portions he paid in cash are not shown, these cancelled notes do indicate something about the extent of Brewster's patronage. ${ }^{13}$ Though the names of firms in Boston, Pittsburgh, and St. Louis appear on invoices in the early to mid1850s, Brewster still bought most heavily from Philadelphia wholesalers. Not until March, 1856, did he begin buying from New York, when he placed an order totaling $\$ 649.13$ with the wholesale grocery firm Livingston Brothers \& Kinkead. In August of the same year, Brewster ordered another $\$ 1,071.12$ of goods from Livingston Brothers, and a total of $\$ 1,251.01$ from two New York yard goods wholesalers. From that point on, Brewster bought his merchandise from a wider variety of wholesale houses in several cities, including an increasingly diverse group of suppliers in Chicago after 1860. ${ }^{14}$

Brewster apparently hand-picked his merchandise throughout the decade of the 1850s during buying trips to the East. The early promissory notes to Philadelphia wholesalers before 1850 indicate a regular pattern for such trips, and Philadelphia hotel receipts for the years 1855,1856 , and 1857 confirm the pattern. In late February or early March, Brewster would travel first to Boston, then to Philadelphia, and finally to Pittsburgh, before returning home to Fort Madison. He may have eliminated Boston from his itinerary after 1854. In that year, he started his purchasing in Boston on February 28 with an order for shoes, boots, and leather trunks from Potter, Elder \& Nute, totaling $\$ 760.38$. Four days later, he completed purchases totaling $\$ 1,339.85$ in yard goods and men's clothing from two other Boston houses. He

${ }^{13}$ Brewster Papers, Folder 1, DSHS. No figures are available for 1845 , but the value of his stock of merchandise in 1847 and 1848 was estimated at $\$ 6,000$ and $\$ 10,000$ respectively, R. G. Dun and Co. Credit Ledgers, Iowa, Vol. 31, p. 230, Dun and Bradstreet Collection, Manuscript Division, Harvard University Baker Library, (hereafter cited as HUBL).

${ }^{14}$ Brewster Papers, Folders 18-21, DSHS. 
then moved on to Philadelphia, where on March 6 and 7 he bought a total of $\$ 2,404.41$ in yard goods from two Philadelphia wholesale firms and $\$ 107.79$ in men's hats and boys' caps from a third. On March 9, he bought a small order of latches, locks, and coffee mills, amounting to $\$ 40.85$ from Livingston, Roggen \& Company in Pittsburgh. ${ }^{15}$ From 1856 to 1857, Brewster seems to have shifted his patronage from Boston to New York, but it is not certain that he replaced Boston with New York in his trip itineraries. Nor is it certain what proportion of his total stock of merchandise these eastern goods represented. There are scattered receipts from St. Louis suppliers in the late 1840 s which would indicate that Brewster needed to replenish at least part of his stock periodically, but that the quantities involved were too small to justify shipping costs from the East.

Brewster's buying trips to the East helped build and reinforce his trade relationships with certain wholesale merchants which, over time, became a fairly sophisticated network of business contacts. Brewster's use of this network of contacts was a factor not only in the success of his dry goods business, but also in the success of his auxiliary enterprises. Large mercantile houses performed a number of services for favored patrons above and beyond those directly connected to sales. The houses honored drafts written on the patron's standing accounts and issued to third parties, a system similar to modern checking accounts. They gave advice on a range of subjects, such as the current availability of specie or the current discount rates on certain paper currencies. ${ }^{16}$ They quoted local market prices on civic bonds and commercial paper, and bought them, for a fee, if the patron so requested. They invested their patron's funds in short-term investments. Though they performed many of these services for a fee (or interest charges in case of drafts written on standing accounts), they expected and received reciprocal treatment from their patrons.

${ }^{15}$ All totals are exclusive of shipping and insurance charges. Brewster Papers, Folder 18, DSHS.

${ }^{16}$ This advice on currency was most particularly pertinent prior to the national banking acts of 1863 and 1865 which standardized banking practices and stabilized currency values. Erling A. Erickson, Banking in Frontier Iowa, 1836-1865 (Ames: The Iowa State University Press, 1971), 96, 115. 
An unascertainable but apparently large part of Brewster's store trade was transacted on a credit basis. Much of the collected letter correspondence up to the Civil War was concerned with the payment (or non-payment) of credit loans by Brewster's store customers. The volume of business on credit was large enough to justify printing a quantity of promissory notes in advance with the particulars of each transaction to be written in by hand. Six of these cancelled notes survive, ranging from the earliest due date, March 8, 1847, to the latest, October 8, 1854. They were evidently filled in and pre-dated, making the due date unambiguously clear from the wording of the note. The largest of the six notes is for $\$ 37.24$, in the note due January 2,1849 . The smallest amount is $\$ 3.00$ in the note due February 24, 1850. The latest note, due October 9, 1854, shows an amount of \$6.97. Four of the notes are for less than ten dollars, fairly small amounts. Among Brewster's varied clientele apparently were people of very limited resources. Perhaps it is indicative of Brewster's business success, not to mention his attention to detail, that even those customers making small purchases were not turned away for lack of cash.

These cancelled credit loan notes point to the acumen of Brewster's business practices. A less cautious merchant might not have required signed promissory notes for small amounts, at least not after his own credit standing and regular trade were established. By 1847, Brewster's credit rating, his ability to assume and discharge debts, was deemed excellent by R. G. Dun \& Company, the leading national credit rating bureau. He carried a stock of merchandise valued at $\$ 6,000$, and a Dun credit rating report in that year rated him Fort Madison's 'best merchant." All subsequent credit reports attest to his growing business and solid credit. ${ }^{17}$

Brewster may have profited modestly, but not dramatically, from interest charges on his customers' accounts. A perusal of his business correspondence indicates that he did not charge more than ten percent on credit accounts. Furthermore, Brewster did not give his credit customers shorter time terms than he, himself, received from his wholesale suppliers. Though increas-

${ }^{17}$ Dun Credit Ledgers, Iowa, Vol. 31, pp. 230-238.7, HUBL. 
ingly his purchases of merchandise involved cash and price discounts for cash, particularly from 1858 on, the earlier credit arrangements between Brewster and his wholesalers called for ten percent interest per annum with the total amount due in one year. ${ }^{18}$ Brewster might have levied stiffer credit terms, but in doing so, he would have run the risk of alienating customers, and losing business. He realized that if his mercantile business suffered, his other business pursuits would suffer, as well.

Charles Brewster's dry goods store was the hub of his economic interests, and his other entrepreneurial activities radiated out from that hub. The store in Fort Madison was where Brewster met the public. Within the context of daily trade, he gauged that public's needs and resources, and he established his market. In so doing, he built up a complex of business and personal relationships. As Brewster's store prospered, so did his other business ventures. In fact, they all prospered so well that by 1870 , at the age of fifty-three, Brewster informally retired from the store business, with his total assets estimated at $\$ 75,000$ to $\$ 100,000$, roughly half of which was in real estate. ${ }^{19}$

BREWSTER ARRIVED in Fort Madison too late to be a town builder, and there is no real evidence that he wholesaled dry goods merchandise to smaller shopkeepers. There is, however, considerable evidence that Brewster developed markets for farm products, and wholesaling farm commodities was the first spoke in Brewster's wheel. In the days of relative cash scarcity (up to the Civil War in Brewster's case), merchants accepted in payment a variety of farm commodities, such as pork, corn, wheat, oats, eggs, butter, and beeswax. The local town market might buy a portion of these items from the merchants and perhaps the emigrants passing through the town might buy more of them. The balance had to be sold wherever buyers could be found. Some merchants, such as J. M. D. Burrows of Davenport, sold to wholesale markets in St. Louis, Cincinnati, or New

${ }^{18}$ Brewster Papers, Folders 1-7, DSHS.

${ }^{19}$ Dun Credit Ledgers, Iowa, Vol. 31, p. 207, HUBL; The Ninth Census of the United States: 1870, Population Schedules, Iowa, Lee County, 17, microfilm, DSHS. 
Orleans, or to the federal government in contracts to supply military outposts. ${ }^{20}$ When local market economies became firmly established on a cash basis with an adequate supply of circulating media, the acceptance of farm commodities in barter was no longer necessary. Charles Brewster, however, continued to deal in large quantities of farm commodities at least until 1865.

The records concerning farm produce prior to the early $1850 \mathrm{~s}$ are too fragmentary to ascertain when Brewster started wholesaling. ${ }^{21}$ By 1854 , however, he was well started, if not firmly established in the trade. In July and August of that year, he shipped a total of 2,194 bushels of corn and 104 bushels of wheat to the Chicago wholesale produce firm of Haughteling and Shepard. His gross receipts for sale of the grain were $\$ 1,235.70$. After he paid for boat and railroad charges, and storage and commission fees on the grain, and return freight charges on purchases of 100 barrels of salt in 1854 and 160 more barrels in January, 1855, Brewster owed the Chicago dealers $\$ 52.06 .{ }^{22}$ There are no records of further grain deals with Haughteling and Shepard, although he continued to order salt from them.

Brewster developed market outlets for farm commodities, including grain, butter, and eggs, outside of commercial wholesale markets. For example, the lumbering firm of McComb, Simpson, and Company of Stillwater, Minnesota Territory, requested in a letter dated September 8, 1854, that Brewster ship them at least 1,500 pounds of butter between that date and the close of navigation on the Mississippi. The following February, the same firm ordered 1,000 to 1,500 bushels of oats, plus any available butter and eggs to be put "on the first through Boat,"

${ }^{20}$ For a description of produce trade and government contracts in the early 1840s, see chs. IX, XI, XII, and XIV in J. M. D. Burrows, My Fifty Years in Iowa (Davenport, Iowa: Glass and Company, Printers and Binders, 1888).

${ }^{21}$ The earliest clue of Brewster's wholesaling is a receipt dated Oct. 6, 1848, for $\$ 48.20$ for "Gunny Bags" from Berthold, Ewing and Co., St. Louis, Brewster Papers, Folder 1, DSHS.

${ }^{22}$ Haughteling and Shepard statements of account, Aug. 30, 1854, and July 17, 1855, Brewster Papers, Folders 3, 4, DSHS. 


\section{The Annals of Iowa}

adding that payment could be expected that spring "as soon as lumber can be got to market." 23 Unlike Burrows, Brewster did not supply Fort Snelling, but it is clear that he knew the route.

A Galena firm, Burrischter and Hellman, wrote in May, 1856, requesting that Brewster send them five or six barrels of eggs immediately, "and as many more every week, or whenever you have enough. . . ." They also asked that he ship 500 or 600 bushels of oats to J. F. Rehse in Hastings, Minnesota (Territory) and to bill them. This letter is instructive not only for pointing up contemporary regard for freshness in eggs but also for the value of public opinion. The writers stated that they did not know Brewster directly but they knew of his reputation through one of his customers. ${ }^{24}$

Butter making in this period was entirely a cottage industry, and the quality of butter could and did vary from household to household. An example of the role of butter and eggs in trade for merchandise from Brewster's store comes from one of the few surviving customer account statements. S. P. Loomis made purchases totaling $\$ 26.89$ between February 14 and June 12 , 1856. He discharged $\$ 7.90$ of that debt, in 66 days in the same year, with credit for items Brewster accepted in payment. On April 7, Loomis was credited with $\$ 1.76$ for 22 dozen eggs, and $\$ 1.65$ for 11 pounds of butter. On May 1, he was credited $\$ 1.25$ for $201 / 2$ dozen eggs. On June 5 , he was credited $\$ 1.20$ for 8 pounds of butter. On June 13, the last recorded transaction, he was allowed $\$ .88$ for 11 dozen eggs, and $\$ .83$ for $62 / 3$ pounds of butter. In those 66 days Loomis brought in a total of $531 / 2$ dozen eggs and $25 \% / 3$ pounds of butter. Whether accepted in trade or paid for in cash, butter and eggs remained staple items of Brewster's wholesale trade at least into $1865 .^{25}$

Brewster was also wholesaling pork as early as 1855 , but the first records of pork and lard sales date from 1858. In March of

${ }^{23}$ Ibid.

${ }^{24}$ Brewster Papers, Folder 5, DSHS.

${ }^{25}$ Brewster Papers, Folder 5, DSHS. The remaining thirty-three cents credited were for thirteen pounds of "Raggs" at one and one half cents per pound. See J. E. Johnston of Keokuk to Brewster, Feb. 28, 1865, requesting a shipment of 25 to 150 dozen eggs and up to 100 pounds of butter, Brewster Papers, Folder 14, DSHS. 
that year, he shipped 60 barrels of lard down river to New Orleans. From New Orleans, the lard was carried on the ship $\mathrm{Au}$ gustus to New York to the wholesale firm of E. D. Morgan \& Co. After deduction of freight, insurance, weighing, and commission charges, Brewster netted $\$ 1,068.13 .{ }^{26}$ A certificate of inspection dated May 10,1858, shows that Brewster also sold pork to the St. Louis firm, Wm. L. Ewing and Company. ${ }^{27}$ With the opening of the Civil War and the diversion of commercial traffic from the Mississippi to the rail system linking lowa with the eastern markets, Brewster shipped his pork and lard by rail to New York. For example, on June 2 and 3, 1863, Brewster shipped a total of 322 barrels of pork to the New York produce wholesale house, A. H. Pomroy and Company. Three barrels were lost in transit and one more did not weigh out to a full barrel. The remaining 318 barrels sold for $\$ 2,164.97$, but freight and other attendant costs were not listed. Pomroy's letter to Brewster, dated September 12, stated that the sale of 104 packs of lard brought Brewster $\$ 2,470.11$, but again, no freight and sales costs were given. ${ }^{28}$

LIKE OTHER merchants in similar conditions of early market development, Charles Brewster offered a variety of banking services. He took time and demand deposits, he exchanged currencies and currency for specie, he forwarded funds, he made loans, and he performed some overlapping banking and mercantile services. When he made the formal shift from dry goods merchant to banker in 1875 , Brewster brought with him considerable banking experience and presumably a readymade clientele. Indeed, it could be said that Brewster was continuously involved in banking, albeit informally, nearly from the beginning of his mercantile career. The earliest record

${ }^{26}$ Brewster Papers, Folder 7, DSHS. Before kerosene became widely available, lard was often used as lighting fuel. For first record of Brewster's pork packing, see Dun Credit Ledgers, Iowa, Vol. 31, p. 230, HUBL.

${ }^{27}$ Brewster Papers, Folder 7, DSHS.

${ }^{28}$ A. H. Pomroy and Company to C. and J. Brewster, June 8 and Aug. 13, 1863, Brewster Papers, Folder 12, DSHS. The letter of Sept. 12 does not indicate what a "pack" of lard was, or how it was different from a barrel. 
of his banking activities is a demand deposit receipt dated May 27, 1847, stating, "Recd of Charles Brewster Fifteen Dollars left by James W. Johnston," and signed by James F. Morrison "For James Wilson." 29

In the context of Brewster's complex of personal and business relationships, his customers came to rely on him for banking services, the second spoke of his wheel of enterprises. Banking services became such a routine part of dealings with store customers that the lines of distinction between mercantile and banking functions often became blurred. For example, in a letter from Edward Bullard of Wacoota, Minnesota, dated December 17, 1859, Bullard stated that a Mr. Paulk would pay off a personal note of $\$ 1,120$ due January 1,1860 , to Brewster because Brewster was holding the note for safekeeping. When Paulk paid the $\$ 1,120$ to Brewster, Bullard wanted Brewster to distribute the proceeds in three ways. First, payment should be made on Bullard's daughter's bills from the boarding school in Denmark, Iowa, and to settle her account at Brewster's store. Second, $\$ 20$ each was to be paid to Sewall Morrell and Judson Morris for Bullard's small personal debts. Third, Brewster was to "... remit the balance in a draft on Chicago or New York ... .," whichever Brewster thought best. From this letter it is clear that Brewster acted simultaneously as banker and merchant. He held the note for a second party and received payment in liquidation of that note by a third party; paid himself for store goods; exchanged currency for another mode of payment; and functioned as a clearing house in forwarding funds to four different parties. ${ }^{30}$

Two letters from a C. F. Taylor also show the overlapping of banking and mercantile services. The first letter, dated September 20, 1864, is written from Fort Pickering, Tennessee, where Taylor served as a chaplain in the Union Army. Most of the letter is concerned with how he wished Brewster to send him $\$ 500$

\footnotetext{
${ }^{29}$ Brewster Papers, Folder 1, DSHS.

${ }^{30}$ Brewster Papers, Folder 8, DSHS. Paulk may not have made the payment due date, as indicated by a later record, dated Dec. 4, 1860, in which Edward Bullard granted Charles Brewster power-of-attorney to collect payment from Fernando Paulk. Lee County Deed Records Lands, Vol. B (1859-1863), p. 297.
} 
left with Brewster by a member of Taylor's family. Before closing, Taylor added, "I would like you to have some first rate butter maker-Mrs. Eoff for instance-pack me a jar of at least 50 or $60 \mathrm{lbs}$, by the middle of Oct." The second letter, dated December 20, 1865, from Fort Pickering, asked what Brewster's price would be to ship 2,000 pounds of bacon and 500 bushels of corn from Fort Madison to Taylor's farm near Fort Pickering. He also asked Brewster to pay on Taylor's personal notes to two other parties. ${ }^{31}$

Brewster's store customers were not alone in expecting such overlapping services. In June, 1858, the partners of the Philadelphia wholesale house, Williamson Taylor \& Company, with whom Brewster traded regularly, sent Brewster a note due them by a third party in Dubuque. They were not familiar with any reputable private banking houses in Dubuque, so they sent it to Brewster, their client and friend, to arrange for collection. ${ }^{32}$

Brewster's banking activities may have led him into investment opportunities, such as speculation in state auditor's warrants. A letter dated February 26, 1857, from James Stevens, asked Brewster to exchange Stevens' enclosed draft for $\$ 100$ for gold, deduct his fee for exchange, and to remit the balance to Mrs. Anne Stevens. ${ }^{33}$ Brewster received payment in kind, rather than money, for an undetermined part of his dry goods sales. What currency Brewster saw varied greatly in origin and value. Where, then, did he obtain the gold for exchange, and also for payment to his eastern suppliers? Though he possibly received some gold in payment from customers, he obtained a large but undetermined amount of it from his speculation in state auditor's warrants, a third spoke in his wheel.

There has been very little published research on the subject of state auditor's warrants in Iowa and their importance as a circulating medium prior to legalization of banks of issue in the

${ }^{31}$ Brewster Papers, Folders 17, 14, DSHS.

${ }^{32}$ Brewster to Williamson Taylor and Co. (Philadelphia), June 11, 1858; Brewster to Knapp Stout and Co. (Dubuque), June 26, 1858, Brewster Papers, Folder 7, DSHS. Both of these are marked "coppy," and are among the few surviving papers in Brewster's own handwriting.

${ }^{33}$ Brewster Papers, Folder 6, DSHS. 
state in $1858 .{ }^{34}$ The warrants were issued by the state in payment for goods and services obtained by state agencies and for salaries of state employees. The warrants could be presented for payment in the state treasurer's office in Des Moines (earlier, in Iowa City), and redeemed. If the warrants could not be presented for payment in the state treasurer's office in Des Moines, the warrant holders obtained cash by other means. One procedure involved signing the warrants over to someone in the state capital who would act as the warrant holder's agent in the redemption, usually for a fee. In a second procedure, the warrant holder or his agent, presented them to a county treasurer, who might or might not redeem them, depending on his current supply of specie and currency. In a third procedure, perhaps the easiest of all, the warrant holder used his warrants as currency in the general market place, wherever they would be accepted. A probable condition for acceptance of a warrant in payment was a discount on the warrant's face amount. It was this discount which made speculation in warrants potentially lucrative for those, like Brewster, who had the means.

Brewster probably obtained his warrants from several sources. For an undetermined period in the mid-1850s, he served in a salaried capacity as a board director of the state penitentiary located in Fort Madison, along with Dr. George Shedd. Shedd and Brewster received payment of their salaries in state auditor's warrants, and Shedd acted for both of them in presenting the warrants at the state treasurer's office on at least one occasion. ${ }^{35}$ Brewster also may have sold merchandise and foodstuffs on contract to the state penitentiary, for which he would have been paid in warrants, but there are no records of such contracts. Brewster may also have accepted the warrants in payment for goods from his store, which seems likely in the case of the smaller warrant denominations of forty dollars or less. ${ }^{36}$ The final possibility is that Brewster bought up warrants

${ }^{34}$ Warrants are not treated as a circulating medium either by Erickson, or by Howard H. Preston in his work, History of Banking in Iowa (Iowa City: The State Historical Society of Iowa, 1922).

${ }^{35}$ George Shedd to Brewster, Feb. 9, 1858, Brewster Papers, Folder 7, DSHS.

${ }^{36}$ Cf. J. B. Stewart to Brewster, June 5, 9, 1860, Brewster Papers, Folder 9 , DSHS. 
of large denominations from warrant holders or elsewhere. ${ }^{37}$ The advantages of trafficking in the warrants must have been attractive to Brewster. He could buy them (or accept them) at a discount, send them to an agent in the state capital for redemption, and receive gold from the state treasury. After he paid for the agent's fees and express charges for sending the gold to Fort Madison, Brewster still could have made a profit.

With this pipeline for gold (and occasionally eastern bank drafts and currency), Brewster had a steady money supply for exchange purposes and for payments to his eastern suppliers. The pipeline was not without its bottlenecks, however. According to various letters to Brewster from his Des Moines agent, J. B. Stewart, the state treasury was chronically short of funds. Warrants were not redeemed promptly. There was often a lag time of several months between warrant issue dates and acceptance for redemption. Stewart's letter of December 18, 1860, advised Brewster that at that moment, only those warrants numbered up to 3500 and dating from before March 20, 1860, were being accepted. ${ }^{38}$ The delays in payment may have inconvenienced Brewster somewhat, but considering his growing wealth, the delays probably did not work any special hardships on him. In the absence of more complete records, the extent of Brewster's traffic in warrants is indefinite. He apparently dealt in large enough quantities to have elicited an offer from Austin Corbin, of the Davenport banking house of Corbin and Macklot, for ninety-five cents on the dollar for any $\$ 1,000$ warrants Brewster held. ${ }^{39}$ The pipeline for gold dried up in 1864, when the Iowa General Assembly passed an act requiring the state treasurer to redeem warrants in paper currency instead of specie and for county treasurers to remit their specie to the state treasurer. ${ }^{40}$

${ }^{37}$ A warrant denomination of $\$ 1,000$ is mentioned in Shedd's letter to Brewster, Feb. 9, 1858, Brewster Papers, Folder 7, DSHS.

${ }^{38}$ Brewster Papers, Folder 9, DSHS.

${ }^{39}$ Austin Corbin to Brewster, Jan. 28, 1862, Brewster Papers, Folder 11, DSHS.

${ }^{40}$ Act of March 10, 1864, Ch. 43, Sec. 3, 4, Tenth General Assembly (Des Moines: F. W. Palmer, State Printer, 1864), 43. 
Another spoke in the wheel of Brewster's enterprises was his land dealings. On his own behalf, Brewster bought land in Minnesota Territory in the mid-1850s, Chicago town lots during and after the Civil War, and town lots and farm property in Lee County, Iowa, throughout his merchant years. For others, Brewster performed a number of land agent duties including locating warrants, paying taxes, collecting rents, and selling property. Land was the most substantial of Brewster's auxiliary interests and comprised the lion's share of his total assets by 1875.

Brewster began buying land warrants, the instruments which conveyed public domain lands to private ownership, and locating them in Minnesota Territory by the mid-1850s. He may have become interested in Minnesota land through his farm commodities market contacts there or through former local residents who moved up to Minnesota. The earliest indication of his property holdings there comes from an offer to buy some of Brewster's land from John Cover in Stillwater in February, 1855. ${ }^{41}$ A letter from J. C. Davis, a former Fort Madison resident, urged Brewster to send his warrants to Davis in Dunn County. Davis explained that he, himself, had bought fourteen town lots in the fledgling village of North Piper and that he was planning to buy two and one-half acres adjoining them to divide into twelve more lots. ${ }^{42}$ There is no record of Brewster's participation in Davis' town site scheme, nor any further mention of Minnesota land after 1855.

By no means, however, did Brewster lose interest in land speculation after 1855 . He made use of his wholesale mercantile contacts in the East on at least two occasions in 1857 in pursuit of land transactions. On January 20, 1857, the Philadelphia wholesale house Williamson Taylor \& Company acknowledged Brewster's letter of January 12 with a payment on his account, and responded to his inquiry about the current prices of land

${ }^{41}$ John Cover to Brewster, Feb. 23, 1855, Brewster Papers, Folder 4, DSHS. Another offer to buy, perhaps the same parcel or a different property, came in July of the same year from Isaac Staples of Stillwater. Staples refers to property adjoining "the lake St. Croix." Staples to Brewster, July 16, 1855, Ibid.

${ }^{42} \mathrm{~J}$. C. Davis to Brewster, June 24, 1855, Ibid. 
warrants in their city. "The present price for Land Warrants as selling here, 120 acres, 90 cts. 80 and 160 acres 92 cts. . . ."43

Brewster reciprocated these favors by performing land agent duties. In 1863, Williamson Taylor \& Company asked Brewster to act in their behalf in paying up all taxes in arrears from 1861 on a tract of 160 acres in Lee County owned by one of the firm's partners. ${ }^{44}$ In 1866 , he was asked to record deeds for two more tracts of Lee County land and to recommend "a good and reliable man" to be the firm's agent for their land holdings in Ringgold County. ${ }^{45}$ Though the letters do not say so, Brewster probably advised them in their Lee County land investments.

Brewster also performed land agent duties for Iowans. J. C. Davis, the would-be Minnesota townsite promoter, granted Brewster power-of-attorney to sell his house in Fort Madison in $1855 .{ }^{46}$ In 1859, Shadrach Cole instructed him to offer Cole's 157 acre farm at $\$ 26.50$ per acre surveyed, or for $\$ 3,600$ unsurveyed. Terms were to be "one third down one third in one year the balance in two years ..." and ten percent interest per year on the unpaid balance. ${ }^{47} \mathrm{~W}$. B. Adamson of Cincinnati, Iowa, wrote to Brewster in 1864 asking him to collect rent from the tenant on Adamson's local property and to deduct his fee for collection from the rent received. ${ }^{48}$

Brewster owned a moderate amount of real estate in Lee County, but the county records of his land transactions would

${ }^{43}$ Williamson Taylor and Co. to Brewster, Jan. 20, 1857, Brewster Papers, Folder 6, DSHS. There is no record showing that Brewster later bought some warrants through them, but his inquiry was not one of idle curiosity. He used Livingston Brothers and Kinkead in New York as an intermediary to offer to buy some Missouri land from a New Jersey resident, but his offer was rejected. C. D. Baldwin to Livingston Brothers and Kinkead, Feb. 4, 1857; Livingston Bros. and Kinkead to Brewster, Feb. 6, 1857, Ibid.

${ }^{44}$ Williamson Taylor and Co. to Brewster, Mar. 26, 1863, Brewster Papers, Folder 12, DSHS.

${ }^{45}$ M. Williamson to Brewster, Sept. 26, 1866, Brewster Papers, Folder 15, DSHS.

${ }^{46} \mathrm{~J}$. C. Davis to Brewster, Mar. 19, 1855, Brewster Papers, Folder 4, DSHS.

${ }^{47}$ Shadrach Cole to Brewster, June 14, 1859, Brewster Papers, Folder 8, DSHS.

${ }^{48}$ W. B. Adamson to Brewster, June 11, 1864, Brewster Papers, Folder 13, DSHS. 
hardly cast him in the role of a speculator interested in rapid turn-over at a profit. Between 1852 and 1875, Brewster bought four farms for a total acreage of just over 600 acres. In 1857, he sold the first farm he bought in 1852 for the same price he paid for it, $\$ 2,160$. He sold two other farms, one of sixty-three acres and the other of 100.89 acres, after holding them six and seven years, at a total gross profit of $\$ 1,100 .{ }^{49} \mathrm{His}$ gross annual return on the sale was less than five percent, before taxes, selling costs, or other expenses. It appears that Brewster held the fourth farm until his death. He was somewhat more active in Fort Madison town lot transactions. In addition to his store site, Brewster variously owned eleven full lots and three half-lots between 1845 and 1875. According to the county records, Brewster sold four full lots and five half-lots in this same period..$^{50}$ One of the full lots was sold to satisfy a mortgage Brewster held on it, so it belongs more properly in Brewster's mortgage transactions. One transaction involving a half-lot may have been a trade of the half-lot and $\$ 100$ for two other half-lots and $\$ 100 . .^{51}$ In a third transaction, Brewster appears to have lost $\$ 1,700$ in the 1867 sale of three half-lots which he bought in 1855 . This particular property was originally the site of a steam sawmill, but its commercial possibilities apparently did not materialize. ${ }^{52}$

${ }^{49}$ Lee County Deed Records Lands, Vol. 5 (1851-1854), 337, Vol. A (18561859), 389; Vol. I (1872-1874); 330, 397, Vol. L (1878-1881), 584, Vol. M (1881-1883), 44. These last two farms were both sold after 1875, the end of Brewster's mercantile career.

${ }^{50}$ Fort Madison Corporate [Municipal] Tax Receipts, 1845, 1846, 1849, 1852, Brewster Papers, Folders 1-2, DSHS; Lee County Deed Records Lands, Vols. 3-6, A-B, and Deed Record Lots, Vols. 1, 5.

${ }^{51}$ Cf. deeds Charles Brewster to Robert Herring, April 19, 1864, and Robert Herring to Charles Brewster, April 27, 1864, in Lee County Deed Record Lots, Vol. 1, 274-283.

${ }^{52}$ Cf. deeds Zeno F. Hopkins to Charles Brewster, Nov. 2, 1855, Lee County Deed Records Lands, Vol. 6 (1854-1856), 367, and Charles Brewster, Robert Herring and wives to Jacob Peters and Edward Bullard, April 12, 1867, Lee County Deed Record Lots, Vol. 2, (1865-1868), 420-421. There are no records of the mill's operations in Brewster's papers. The sawmill is not mentioned in Jacob A. Swisher's Iowa, Land of Many Mills (Iowa City: The State Historical Society of Iowa, 1940). 
Overall, the records are not complete enough to determine his profits on town lots.

Between 1865 and 1870, the bulk of Brewster's real estate holdings may have been in Cook County, Illinois, rather than Lee County, Iowa. J. H. Little, a former Fort Madison resident and Brewster's close friend, lived in Chicago in these years and he was co-proprietor of Reno \& Little, a coal and lumber yard. According to letters in April, 1863, Little helped Brewster buy a Chicago lot, comprising a quarter city block, at the corner of Lake and Page streets in that year. In 1865, at Brewster's request, Little arranged to have architectural plans drawn up for building three wooden houses on the lot as income property. Brewster bought at least one more Chicago lot in 1866, and in 1867 , he sold a lot. ${ }^{53}$ These letters are only fragmentary evidence, and without a search of Cook County deed records for these years, the full extent of Brewster's Chicago holdings cannot be ascertained. The 1870 federal census and contemporary credit rating reports do provide some solid clues, however. The 1870 federal census lists his total real estate value as $\$ 42,000$, and his personal estate at $\$ 11,800 .{ }^{54}$ Credit rating entries of the same year put his total assets at $\$ 75,000$ to $\$ 100,000$, note that the bulk of his assets are in real estate form, and that he is "interested in Chgo lots." Because his Lee County land holdings were not very extensive in 1870 , it is safe to assume that the $\$ 42,000$ census figure is an estimate including his Chicago property, and the R. G. Dun reports confirm this assumption. An 1872 credit rating report estimated that Brewster owned a minimum of $\$ 50,000$ property in Chicago, alone. ${ }^{55}$

A fourth spoke in Brewster's wheel, mortgage loans, was an overlapping of his interest in land and his banking functions.

${ }^{53} \mathrm{~J}$. H. Little to Brewster, April 6, 13, 18, and 27, 1863; J. H. Little to Brewster, July 17, 1865; Brewster to Abner Reeves, April 12, 1866; duplicate copy of deed, Charles and Eliza Jane Brewster to John O'Kane, Mar. 9, 1867; and Abner Reeves to Brewster, Mar. 15, 1867, Brewster Papers, Folders 12, 14, 15 , 16 , DSHS.

${ }^{54}$ The Ninth Census of the United States: 1870, Population Schedules, Iowa, Lee County, 17.

${ }^{55}$ Dun Credit Ledgers, Iowa, Vol. 31, 207, 238.7, HUBL. 


\section{The Annals of Iowa}

Brewster, like other professional and business people in prairie villages and small towns of the period, lent out cash on land mortgages. ${ }^{56}$ Between 1851 and 1867, he made a total of eighteen mortgage loans in Lee County. Nine were mortgages on farm property, totaling $\$ 6,380$, and the other nine mortgages were on Fort Madison town lots (or half-lots), totaling $\$ 5,911.65 .{ }^{57}$ Brewster did not make any more mortgage loans in Lee County between 1868 and 1875 . Some details in these mortgage transactions are notable. Only two of the eighteen mortgages called for more than ten percent interest, and those two, the two earliest, dating from 1851, called for twelve-anda-half percent interest. The principal amounts were not large to begin with, and the most common due dates were one year or two years. ${ }^{58}$ One probable reason why Brewster did not charge higher interest was because he knew his mortgage debtors personally, and their resources and ability to repay. He loaned money to the same people who bought his merchandise and used his auxiliary services. As they prospered, so did he.

Despite the terms stipulated in the mortgage instruments, few mortgages were paid promptly. Out of the fourteen mortgage transactions on record, the average contract terms were for oneand-a-half years, but the average life of a mortgage was about nine years. Brewster's correspondence from these years does not reveal that he pressed his debtors for payment. Nor do the circuit and district court records reveal that he ever filed suit to foreclose on a mortgage. In fact, Brewster seems not to have been party to any suit in Lee County in his forty-nine years of residence there.

Brewster's mortgage lending was a limited and highly controlled venture. In the sixteen year period, 1851 through 1867 ,

${ }^{56}$ Allan G. Bogue, From Prairie to Combelt (Chicago: Quadrangle Books, 1968), 175, discusses various sources of mortgage funds.

${ }^{57}$ Lee County Mortgage Records, Vol. 1 (1838-1856), Vol. A (1856-1865), and Vol. B (1865-1869); Lee County Deed Record Lots, Vol. 2 (1865-1868), Vol. 3 (1868-1870).

${ }^{58}$ The largest mortgage was for $\$ 1,500$ to William and John Dighton on eighty acres in 1858, Lee County Mortgage Records, Vol. A, 175. The overall average on all eighteen mortgages was about $\$ 682.85$. 
he loaned a total of $\$ 12,291.65$, not a large sum for a man of his resources, but virtually all of it was his own money. The highest number of mortgages Brewster issued in any given year was three, in the year 1857 . He issued no mortgages at all in $1853,1854,1860,1864$, and 1866 . If he had been intent on making profits on mortgages, he should have invested a greater total amount, with more frequency and consistency. To be sure, he probably did not lose money, for if he had, his mortgages would have been far fewer in number and in a more compact period of time. By virtue of Brewster's caution, his preoccupation with other ventures, or both, mortgages stand out as the most sharply defined of his enterprises.

The fifth and final spoke, social services, was not primarily economic in emphasis, but vital, nonetheless, to Brewster's success. Merchants in this era were called upon by their customers and others to give advice, to write letters for the less literate, and to provide letters of introduction to out-of-town businessmen. Merchants also were often prominently involved in civic betterment projects in their home communities. Brewster performed a number of social services for his customers and his community. He most frequently gave advice. Brewster was asked, among other things, for instructions on how to make mortgage loans, what Fort Madison house and town lots were attractive investment properties, and to give the current value of Fort Madison railroad bonds. ${ }^{59} \mathrm{He}$ was sometimes approached for advice or information on matters requiring discretion and confidentiality. A letter to Brewster in 1858 from G. W. Rathbone, president of the Evansville branch of an Indiana bank, asked Brewster to make discreet inquiries about a certain William Bradley. Bradley, a produce dealer in Fort Madison, apparently owed Rathbone's bank, and Rathbone wanted to know his prospects of repayment. Rathbone clearly had his doubts, saying: "I have a letter from him dated recently at your place in which he makes fair promises-but I shall not count his

${ }^{59}$ William Ross to Brewster, Oct. 13, 1856; Horace Stiles to Brewster, Nov. 27, 1854; F. M. Fullerton to Brewster, Nov. 3, 1859; D. Garth to Brewster, Dec. 6, 1865, Brewster Papers, Folders 3, 5, 8, 14, DSHS. 


\section{The Annals of Iowa}

promises until I learn that he is not what I fear he is, a humbug." ${ }^{60}$ Of a similarly confidential nature was a request in 1866 from Josiah Martin, of Monmouth, Illinois, that Brewster check with the clerk of (circuit) court to find out the terms of the will of William McIntire, recently deceased. Martin was inquiring in behalf of McIntire's nieces, who lived in Indiana. He asked Brewster to make contact with the clerk of court because Brewster was the only person Martin knew in Fort Madison. ${ }^{61}$

Social services ranged from small matters, such as getting a watch out of pawn or in recommending a local newspaper for out-of-state residents, to more serious matters involving social welfare. A letter from Lucien Eaton in St. Louis in 1858 requested that Brewster "take charge of the bearer of this, John Nibbs, an orphan boy who is going to my father Geo. C. Eaton . . ." to live. The elder Eaton would pay any expenses Brewster incurred in forwarding the boy safely to his household. ${ }^{62}$

Brewster showed a magnanimous side in dealing with a widow and her children. In 1867, he arranged a mortgage for Rachel Elsroad after the death of her husband. The deceased had run up a debt of $\$ 442$ with Brewster and two other parties, and he was $\$ 400$ in arrears on property taxes. Brewster consolidated all of these debts into a mortgage lien against the family house and lot, after advancing Mrs. Elsroad the money to pay the taxes, leaving the widow and her children their home. The terms of the mortgage-ten percent interest per year, interest payable annually, and the total due in three years-suggest a coldly rational and calculated transaction. The human factor of kindness, however, was very much in evidence. In 1870, Brewster bought the house for taxes when the widow fell into arrears for $\$ 308.09$, preserving her home once again. ${ }^{63} \mathrm{He}$ did not levy

${ }^{60} \mathrm{G}$. W. Rathbone to Brewster, May 27, 1858, Brewster Papers, Folder 7, DSHS.

${ }^{61}$ Josiah Martin to Brewster, Oct. 6, 1866, Brewster Papers, Folder 15, DSHS. Martin may also have recognized his own handicaps in literacy, but the reason stated is that ". . you air all the Person that I am aquant With thair."

${ }^{62}$ Lucien Eaton to Brewster, May 1, 1858, Brewster Papers, Folder 7, DSHS.

${ }^{63}$ Lee County Deed Record Lots, Vol. 3 (1868-1870), 284-285; Vol. 4 (18701872), 189-190. 
any further liens against the Elsroad house, according to county records. He may have absorbed the additional cost without compensation. In 1875 , after nearly eight years, he marked the original mortgage satisfied in full.

Brewster apparently never held elective political office, nor high positions in his church. His services to the community at large were relatively few and ceremonial. In 1861, he was named to a committee of five to organize and administer the town relief fund for the families of Fort Madison volunteers to the Union Army ${ }^{64} \mathrm{He}$ may have arranged the town's purchase of $\$ 13,000$ of capital stock in the Fort Madison and Rockford Railroad, according to a draft of a resolution Brewster drew up for town council adoption. ${ }^{65}$ Most of Brewster's social services were of a direct and personal nature to people identified with one or more of his business ventures. If Brewster's convictions played an important role in his social services, it is also clear that non-economic accommodations to the public were appropriate to his integrated economic context of enterprise. He may not have thought of it that way, but his social services could be seen as another cost of doing business.

Charles Brewster served many of the same functions as did the merchant capitalist of an earlier frontier period. He met the initial challenges of a relatively unsophisticated local economy with an appropriate combination of entrepreneurial skills and cautious pragmatism. In this, he was representative of merchants operating in similar early stages of economic development.

Brewster's shift from merchandising and his auxiliary ventures to banking in 1875 was appropriate to an altered economic picture. While his change in principal occupations owed much to his own enhanced financial position and local banking business opportunities, it was also reflective of the growth of a more sophisticated economy over the preceding thirty years. Na-

${ }^{64}$ The History of Lee County, Iowa (Chicago: Western Historical Company, 1879), 556.

${ }^{65}$ Brewster Papers, Folder 16, DSHS. The year is uncertain as there is no date on the resolution draft. Brewster apparently wanted the resolution passed, stating that he had delivered the stock to the town council, to protect himself against possible later litigation. 
tional banking and currency legislation, the proliferation of new manufacturing and marketing, the rise of large corporations - all contributed to the new conditions Brewster faced and to which he responded. A greater economic maturity had arrived, characterized by an interlocking of local economic life with the national economy, and reinforced and accelerated by the rail network, which was nearly completed in Iowa in 1875 . It was at this point that Charles Brewster stepped out of the center of his wheel of economic enterprise and stepped into the more linear and specialized business of banking. 
Copyright of Annals of Iowa is the property of State of Iowa, by \& through the State Historical Society of Iowa and its content may not be copied or emailed to multiple sites or posted to a listserv without the copyright holder's express written permission. However, users may print, download, or email articles for individual use. 